\title{
O możliwości odmowy przyjęcia lub pozostawienia bez rozpoznania kasacji wniesionej po upływie terminu, o którym mowa w art. 524 § 3 Kodeksu postępowania karnego ${ }^{1}$
}

\begin{abstract}
The aim of this work is to analyse Article 524, $\$ 3$ of Polish Code of Criminal Procedure and, on the basis of the systemic and functional ways of judicial interpretation, to provide the answer to the question about the possibility of refusing to accept (by the president of the court to which the cassation was submitted) or leaving unexamined (by the Supreme Court) the cassation filed against the accused after more than one year of the date on which the judgment has become final, if, at the same time, it is not even theoretically possible, in that particular case, to change the appealed judgment in favour of the accused. The view was expressed that the adoption of the proposed interpretation of this provision would contribute to a significant relief to the Supreme Court, while maintaining all procedural guarantees for the parties, which, according to the author, may be of particular importance, especially during the period of combating the effects of the SARS-CoV-2 pandemic.
\end{abstract}

Keywords: cassation, extraordinary measures of appeal, measures of appeal, Supreme Court, judicial interpretation, systemic interpretation, functional interpretation, criminal proceedings, coronavirus, SARS-CoV-2

\section{Wprowadzenie}

Pomimo że regulacja, zgodnie z którą uwzględnienie kasacji na niekorzyść oskarżonego jest niedopuszczalne, jeżeli została ona wniesiona po upływie określonego czasu liczonego od dnia uprawomocnienia się

${ }^{1}$ Ustawa z dnia 6 czerwca 1997 r. - Kodeks postępowania karnego, Dz.U. 2020, poz. 30, 413 i 568 . 
orzeczenia, funkcjonuje w polskim porządku prawnym nieprzerwanie od chwili wejścia w życie obowiązującej kodyfikacji karnej, a nawet wcześniej $^{2}$, w doktrynie prawa karnego procesowego dopiero niedawno pojawił się pogląd, zgodnie z którym w przypadku kasacji wniesionej na niekorzyść oskarżonego po upływie roku od uprawomocnienia się orzeczenia, gdy w realiach danej sprawy nie jest - nawet teoretycznie - możliwe orzeczenie na jego korzyść, kasację taką należy w trybie art. 531 $\S 1$ zd. 1 k.p.k. pozostawić bez rozpoznania z uwagi na jej niedopuszczalność z mocy ustawy ${ }^{3}$. Wcześniej zaś jednogłośnie przyjmowano, że wyrażony w art. $524 \S 3$ k.p.k. zakaz nie daje podstaw do uznania, iż wniesienie kasacji na niekorzyść oskarżonego po upływie roku (a do 14 kwietnia 2016 r. po upływie 6 miesięcy $^{4}$ ) od daty uprawomocnienia się zaskarżonego orzeczenia jest niedopuszczalne, ani też, że niedopuszczalne jest jej rozpoznanie, ponieważ wyłącza on jedynie możliwość uwzględnienia takiego środka na niekorzyść oskarżonego. Omawiany rodzaj kasacji podlega zatem rozpoznaniu na zasadach ogólnych, tyle tylko, że może co najwyżej spowodować odwrócenie kierunku zaskarżenia i orzeczenie przez Sąd Najwyższy na korzyść oskarżonego w przypadkach, o których mowa w art. 434 § 2 w zw. z art. 518 k.p.k. ${ }^{5}$. Jak pisał S. Zabłocki: „W każdym innym wypadku kasacja wniesiona na niekorzyść oskarżonego po upływie 6 miesięcy [obecnie roku - B.Ł.] od daty uprawomocnienia się orzeczenia powinna zostać oddalona"6.

Przedstawiony wyżej pogląd znajduje zastosowanie również w judykaturze. W ramach przykładu warto uważnie prześledzić układ procesowy, w którym najwyższa instancja sądowa rozpoznawała kasację na niekorzyść osoby poddanej postępowaniu lustracyjnemu (do której z mocy art. 21 ust. 1 Ustawy z dnia 18 października 2006 r. o ujawnianiu infor-

2 Zob. art. 463 § 2 Ustawy z dnia 19 kwietnia 1969 r. - Kodeks postępowania karnego, Dz.U. nr 13, poz. 96 ze zm.; por. art. 417 Rozporządzenia Prezydenta Rzeczypospolitej Polskiej z dnia 19 marca 1928 r. - Kodeks postępowania karnego, Dz.U. 1949, nr 33, poz. 243, zgodnie z którym „Uwzględniając nadzwyczajną rewizję, założoną na niekorzyść oskarżonego po upływie sześciu miesięcy od dnia uprawomocnienia się orzeczenia, Sąd Najwyższy ogranicza się tylko do ustalenia uchybień".

3 Tak J. Matras. W: Kodeks postępowania karnego. Komentarz. Red. K. DudKa. Warszawa 2018, teza 7 do art. 524; ostatnio tak również W. KozIELEWICz. W: Kodeks postępowania karnego. T. I. Komentarz. Art. 1-424. Red. D. Drajewicz. Warszawa 2020, Nb. 5 do art. 524.

${ }^{4}$ Por. art. 1 pkt 125 Ustawy z dnia 11 marca 2016 r. o zmianie ustawy - Kodeks postępowania karnego oraz niektórych innych ustaw, Dz.U. poz. 437 i 2103 oraz Dz.U. 2017, poz. 1139 i 1452.

${ }^{5}$ D. ŚwIECKI. W: Kodeks postępowania karnego. Komentarz. Wyd. 4. Red. J. SKoruPKA. Warszawa 2020, s. 1364.

${ }^{6}$ S. ZAвŁOCKI. W: Kodeks postępowania karnego. Komentarz. T. I. Red. Z. GostYŃsKI. Warszawa 1998, teza 14 do art. 524; podobnie m.in. T. GrZEgOrCZYK. W: T. GrzegOrCZYK, J. Tylman: Polskie postępowanie karne. Wyd. 7. Warszawa 2009, s. 884. 
macji o dokumentach organów bezpieczeństwa państwa z lat 1944-1990 oraz treści tych dokumentów ${ }^{7}$ należy stosować przepisy dotyczące oskarżonego w postępowaniu karnym) od orzeczenia sądu II instancji utrzymującego $\mathrm{w}$ mocy orzeczenie sądu I instancji, w którym rozstrzygnięto, że osoba ta złożyła zgodne z prawdą oświadczenie lustracyjne (do którego $\mathrm{z}$ mocy art. $21 \mathrm{a}$ ust. 1 zd. 2 u.u.i.d. należy stosować odpowiednio przepisy dotyczące wyroku uniewinniającego). W postępowaniu tym Sąd Najwyższy wprawdzie dostrzegł, że została ona wniesiona po upływie terminu, o którym mowa w art. 524 § 3 k.p.k. w zw. z art. 19 u.u.i.d., jak również, iż „ze względu na treść zaskarżonego orzeczenia orzekanie na korzyść osoby lustrowanej nie było możliwe" (nie można wszak wydać orzeczenia korzystniejszego niż w pełni „uniewinniające”), a mimo to postanowił oddalić wniesiony doń środek zaskarżenia ${ }^{8}$.

Podobnie w sprawie dyscyplinarnej jednego z lekarzy dentystów Sąd Najwyższy przyjął, że „Kasacja na niekorzyść obwinionego wniesiona po upływie terminu wskazanego $\mathrm{w}$ art. 96 ust. 2 Ustawy z dnia 2 grudnia 2009 r. o izbach lekarskich ${ }^{9}$, którego odpowiednik stanowi art. 524 $\S 3$ k.p.k., podlega rozpoznaniu, ale nie może być uwzględniona. Może zatem wywołać orzeczenie na korzyść obwinionego, a gdy to nie wchodzi w rachubę - powinna być oddalona". Choć z sytuacją taką sąd kasacyjny miał do czynienia właśnie w przedmiotowej sprawie, w której pełnomocnik pokrzywdzonej zaskarżył $\mathrm{w}$ drodze nadzwyczajnego środka zaskarżenia uniewinniające orzeczenie Naczelnego Sądu Lekarskiego (jak sam zauważył: „[...] wobec uniewinnienia A.K. od popełnienia zarzucanego mu przewinienia zawodowego jeszcze bardziej korzystne orzeczenie zapaść już nie może"), to jednak w tym konkretnym przypadku postanowił pozostawić kasację bez rozpoznania, jednakże nie ze względu na treść art. 96 ust. 2 u.i.l., ale wyłącznie $z$ uwagi na jej wniesienie już po ustaniu karalności przewinienia dyscyplinarnego, co zgodnie z art. 529 k.p.k. w zw. z art. 112 pkt 1 u.i.l. uniemożliwiało samo wniesienie kasacji na niekorzyść, a przez to również jej rozpoznanie ${ }^{10}$.

Warto jednak zwrócić uwagę, że w orzecznictwie można znaleźć również - choć bez wątpienia odosobnione - stanowisko przeciwne. W jednym ze swych orzeczeń najwyższa instancja sądowa przyjęła bowiem,

7 Dz.U. 2020, poz. 306 i 322 [dalej jako: u.u.i.d.].

${ }^{8}$ Post. SN z dnia 18 stycznia 2012 r., V KK 329/11. OSNKW 2012, nr 3, poz. 32, s. 59; zob. również post. SN z dnia 31 marca 2005 r., III KK 182/04. OSNSK 2005, poz. 645 , mocą którego również oddalono kasację na niekorzyść oskarżonej uniewinnionej przez sądy obu instancji wyłącznie z uwagi na jej wniesienie przez pełnomocnika oskarżycieli posiłkowych po upływie terminu z art. 524 § 3 k.p.k.

9 Dz.U. 2019, poz. 965 [dalej jako: u.i.l.].

${ }^{10}$ Post. SN z dnia 17 grudnia 2013 r., SDI 49/13. LEX nr 1403914. 
że przekroczenie terminu wskazanego w art. $524 \S 3$ k.p.k. „,nie zawsze prowadzi do niedopuszczalności kasacji, albowiem także po jego upływie Sądowi Najwyższemu wolno kasację rozpoznać, odwracając jej kierunek. Jest to jednak niemożliwe w wypadku wniesienia kasacji na niekorzyść skazanego od wyroku uniewinniającego", a w konsekwencji postanowiła wniesioną kasację pozostawić bez rozpoznania ${ }^{11}$.

\section{Cel pracy}

Problem tkwi jednak w tym, że zarówno w pracach przywołanych wcześniej przedstawicieli doktryny, jak i w uzasadnieniu przytoczonego postanowienia Sądu Najwyższego nie sposób odnaleźć jakiekolwiek wyjaśnienie dla rozumienia wyrażonego w art. 524 § 3 k.p.k. zakazu uwzględnienia kasacji na niekorzyść oskarżonego wniesionej po upływie roku od daty uprawomocnienia się orzeczenia $\mathrm{w}$ sposób, który już prima vista zdaje się przeczyć dość jednoznacznemu rezultatowi wykładni językowej, a przez to być może stanowi przykład nieuzasadnionej wykładni contra legem. Celem niniejszej pracy jest zatem właśnie przeprowadzenie szerszej analizy omawianego unormowania i udzielenie odpowiedzi na pytanie o możliwość przyjęcia tezy, że w razie wniesienia kasacji na niekorzyść oskarżonego po upływie roku od daty uprawomocnienia się orzeczenia, przy jednoczesnej niemożliwości orzeczenia w danym układzie procesowym na jego korzyść (ewentualnie na korzyść innego uczestnika procesu, jeżeli takie rozstrzygnięcie nie wywołuje dla oskarżonego jakichkolwiek ujemnych konsekwencji ${ }^{12}$ ), sąd kasacyjny uprawniony jest - a być może nawet obowiązany - do pozostawienia przyjętej kasacji bez rozpoznania. Jeśli tak, to jakie argumenty przemawiają za takim sposobem interpretacji art. $524 \S 3$ k.p.k. oraz czy te same względy mogą posłużyć do uznania, że tok rozpoznania kasacji spełniającej oba te warunki powinien zostać przerwany już wcześniej, tzn. na etapie badania kasacji w trybie art. 530 $\S 2$ k.p.k. przez prezesa sądu, do którego wniesiono kasację.

Wydaje się, że praktyczna wartość płynąca z rozstrzygnięcia zarysowanego problemu w najbliższym czasie może się ujawnić w związku z pandemią wirusa SARS-CoV-2. Z uwagi na obawę o swoje życie lub zdrowie, ograniczenia płynące z obowiązku poddania się przymusowej kwarantannie bądź izolacji, jak również utrudnienia w działalności sądów i podmiotów zajmujących się zawodowym doręczaniem korespondencji, wynikające

11 Post. SN z dnia 10 września 2009 r., V KK 55/09. OSNSK 2009, nr 1, poz. 1860.

12 Zob. wyr. SN z dnia 28 lutego 2006 r., V KK 472/05. OSNKW 2006, nr 5, poz. 48, s. 32 . 
z wprowadzenia stanu epidemii, skarżący może w skrajnych przypadkach nie mieć realnej możliwości wniesienia kasacji na niekorzyść oskarżonego w ustawowo przepisanym terminie, albo też - co wydaje się bardziej prawdopodobne - może tkwić w błędnym przekonaniu o możliwości przywrócenia przez sąd nie tylko terminów, o których mowa w art. 524 \$ 1 zd. 1 i 2 k.p.k., ale również terminu z art. 524 \$ k.p.k. (ewentualnie, z uwagi na obowiązujący w postępowaniu kasacyjnym przymus adwokacko-radcowski, liczyć na przekonanie Sądu Najwyższego do odstąpienia od ugruntowanego poglądu o jego materialnoprawnym charakterze $\left.^{13}\right)$. Oznacza to, że zarówno w czasie trwania epidemii wirusa SARS-CoV-2 w Polsce, jak i w okresie następującym bezpośrednio po nim najprawdopodobniej dojdzie do znaczącego wzrostu liczby spraw, w których sąd kasacyjny będzie zmuszony sięgać po dyspozycję wyrażonej w tym przepisie normy. Zwłaszcza że rozważany termin - jako majaccy zdaniem judykatury charakter materialnoprawny, ale równocześnie niedotyczący przedawnienia karalności czynu lub wykonania kary jest jednym $\mathrm{z}$ nielicznych nieobjętych zakresem zastosowania art. 15zzr ust. 6 oraz art. 15zzs ust. 1 Ustawy z dnia 2 marca 2020 r. o szczególnych rozwiązaniach związanych z zapobieganiem, przeciwdziałaniem i zwalczaniem COVID-19, innych chorób zakaźnych oraz wywołanych nimi sytuacji kryzysowych ${ }^{14}$. Przywołane przepisy dotyczą bowiem wyłącznie terminów procesowych i sądowych oraz tej części terminów o charakterze materialnoprawnym, która odnosi się do przedawnienia karalności czynu i przedawnienia wykonania kary w sprawach o przestępstwa, przestępstwa i wykroczenia skarbowe oraz w sprawach o wykroczenia. Warto zaakcentować, że jako regulacje o bez wątpienia wyjątkowym charakterze nie powinny podlegać wykładni rozszerzającej.

Na zakończenie tej części rozważań należy odnotować, że zagadnienie to ma niebagatelne znaczenie również dlatego, że sposób wykładni

13 Zob. wyr. SN z dnia 31 stycznia 2017 r., V KK 360/16. OSNKW 2017, nr 6, poz. 34, s. 34; post. SN z dnia 31 stycznia 2017 r., V KK 333/16. LEX nr 2255440 oraz przywołane już wcześniej post. SN z dnia 31 marca 2005 r., III KK 182/04; odmiennie m.in. I. NowIкоwsкI: Funkcja gwarancyjna terminów w polskim kodeksie postępowania karnego. „Studia Iuridica Lublinensia” 2013, nr 20, s. 31, który opowiada się za ściśle procesowym charakterem tego terminu; zob. również Idem: O regułach obliczania terminów $w$ procesie karnym (kwestie wybrane). W: Teoretyczne i praktyczne problemy współczesnego prawa karnego. Księga jubileuszowa dedykowana Profesorowi Tadeuszowi Bojarskiemu. Red. A. Michalska-Warias, I. Nowikowski, J. Piórkowska-Flieger. Lublin 2011, s. 893.

${ }_{14}$ Dz.U. poz. 374, 567, 568 i 695; odmiennie, choć również uznając materialnoprawny charakter tego terminu, A. SAKowicz. W: Kodeks postępowania karnego. Komentarz. Wyd. 9. Red. Idem. Warszawa 2020, Nb. 21 do art. 524. 
omawianych przepisów przyjęty na gruncie postępowania karnego sensu stricto będzie miał zastosowanie także w:

1) postępowaniu $\mathrm{w}$ sprawach o przestępstwa skarbowe i wykroczenia skarbowe (arg. ex art. 524 § 3 k.p.k. w zw. z art. $113 \S 1$ Kodeksu karnego skarbowego ${ }^{15}$;

2) postępowaniu prowadzonym na podstawie Kodeksu postępowania w sprawach o wykroczenia ${ }^{16}$, w którego art. 110 § 2 przewidziano bliźniaczą regulację, w myśl której niedopuszczalne jest uwzględnienie kasacji na niekorzyść obwinionego wniesionej po upływie 3 miesięcy od daty uprawomocnienia się orzeczenia;

3) postępowaniu $\mathrm{w}$ przedmiocie odpowiedzialności podmiotów zbiorowych za czyny zabronione pod groźbą kary jako przestępstwa lub przestępstwa skarbowe (arg. ex art. 524 § 3 k.p.k. w zw. z art. 22 zd. 1 Ustawy z dnia 28 października 2002 r. o odpowiedzialności podmiotów zbiorowych za czyny zabronione pod groźbą kary ${ }^{17}$ ) oraz

4) postępowaniach dyscyplinarnych, w których przepisy rozdziału 55 k.p.k. stosuje się odpowiednio lub w odniesieniu do których ustawodawca przewidział regulację co najmniej podobną do art. 524 $\S 3$ k.p.k. ${ }^{18}$.

\section{Zagadnienie wykładni}

\subsection{Wykładnia językowa}

Analizę tytułowego zagadnienia należy rozpocząć od powtórzenia, że literalne brzmienie art. $524 \S 3$ k.p.k. nie daje podstaw do przyjmowania, że sąd kasacyjny może w opisanych wyżej przypadkach wydać orzeczenie inne aniżeli oddalające wniesiony doń nadzwyczajny środek zaskarżenia. Bez wątpienia niedopuszczalność samego uwzględnienia konkretnej

15 Ustawa z dnia 10 września 1999 r. - Kodeks karny skarbowy, Dz.U. 2020, poz. 19, 568 i 695.

${ }^{16}$ Ustawa z dnia 24 sierpnia 2001 r. - Kodeks postępowania w sprawach o wykroczenia, Dz.U. 2020, poz. 729.

17 Dz.U. 2020, poz. 358.

18 Oprócz przywołanego już wcześniej art. 96 ust. 2 u.i.l. zob. art. 46c ust. 2 Ustawy z dnia 21 grudnia 1990 r. o zawodzie lekarza weterynarii i izbach lekarsko-weterynaryjnych, Dz.U. 2019, poz. 1140, art. 46c ust. 2 Ustawy z dnia 19 kwietnia 1991 r. o izbach aptekarskich, Dz.U. 2019, poz. 1419, art. 58c ust. 2 Ustawy z dnia 27 lipca 2001 r. o diagnostyce laboratoryjnej, Dz.U. 2019, poz. 849 oraz Dz.U. 2020, poz. 567, art. 73 ust. 6 Ustawy z dnia 1 lipca 2011 r. o samorządzie pielęgniarek i położnych, Dz.U. 2018, poz. 916 oraz art. 120 ust. 4 Ustawy z dnia 25 września 2015 r. o zawodzie fizjoterapeuty, Dz.U. 2019, poz. 952 oraz Dz.U. 2020, poz. 567. 
kasacji a contrario oznacza przecież dopuszczalność jej przyjęcia i rozpoznania. Tym niemniej - w sposób zdecydowany opowiadając się w tym miejscu za wypracowaną głównie $w$ poznańskiej nauce teorii prawa derywacyjną koncepcją wykładni - należy przyjąć, że procesu wykładni przepisów prawa karnego procesowego nie wolno kończyć na etapie analizy językowej, ale uzyskane $\mathrm{w}$ ten sposób rezultaty powinno się weryfikować przy zastosowaniu dalszych dyrektyw interpretacyjnych ${ }^{19}$. Jak bowiem trafnie przyjęto $\mathrm{w}$ uzasadnieniu jednej z uchwał siedmioosobowego składu Sądu Najwyższego, „nawet jasny i oczywisty wynik wykładni językowej nie zwalnia interpretatora z obowiązku odwołania się także do innych dyrektyw wykładni, w szczególności systemowych i funkcjonalnych, choćby w celu zbadania, czy rezultat analizy językowej nie jest nieracjonalny lub aksjologicznie nieakceptowalny"20.

\subsection{Wykładnia systemowa}

Przechodząc do rozważań na temat systemowej wykładni art. 524 § 3 k.p.k., warto rozpocząć od zwrócenia uwagi na rolę wyznaczoną najwyższej instancji sądowej przez przepisy rangi konstytucyjnej. Zgodnie z art. 183 ust. $1 \mathrm{w}$ zw. z art. 175 ust. 1 Konstytucji RP ${ }^{21}$ Sąd Najwyższy powołany jest do sprawowania wymiaru sprawiedliwości m.in. poprzez nadzór nad działalnością orzeczniczą sądów powszechnych i wojskowych. Nieprzypadkowe jest również umieszczenie przez ustrojodawcę tego sądu jako pierwszego $\mathrm{w}$ wyliczeniu zawartym $\mathrm{w}$ drugim $\mathrm{z}$ przywołanych przepisów ustawy zasadniczej, które określa jego miejsce w strukturze wymiaru sprawiedliwości ${ }^{22}$.

Skoro więc Sąd Najwyższy stoi na czele struktury sądownictwa, a równocześnie jest on jedynym tego typu sądem w kraju, to oczywiste jest, że powinien rozpoznawać jak najmniej spraw, a ściślej - jedynie te, w których chodzi o rozstrzyganie o najważniejszych interesach

19 B. ŁuKowiak: Zakres podmiotowy zwiazania zapatrywaniami prawnymi sqdu odwoławczego $w$ postępowaniu karnym. „Veritas Iuris” 2019, nr 1, s. 62 oraz przywołana tam literatura i orzecznictwo.

${ }^{20}$ Uchw. SN (7) z dnia 29 października 2012 r., I KZP 15/12. OSNKW 2012, nr 11, poz. 111, s. 1; por. M. ZIELIŃsKI: Koncepcja derywacyjna wykładni a wykładnia $w$ orzecznictwie Izby Karnej i Izby Wojskowej Sadu Najwyższego. W: Zagadnienia prawa dowodowego. Red. J. GodyŃ, M. HudzIK, L.K. PAPRZYCKI. Warszawa 2011, s. 117-136.

${ }^{21}$ Ustawa z dnia 2 kwietnia 1997 r. - Konstytucja Rzeczypospolitej Polskiej, Dz.U. nr 78, poz. 483, Dz.U. 2001, nr 28, poz. 319, Dz.U. 2006, nr 200, poz. 1471 oraz Dz.U. 2009, nr 114, poz. 946.

${ }^{22}$ Tak trafnie P. WilińsKi, P. KarLiK. W: Konstytucja RP. T. II. Komentarz. Art. 87-243. Red. M. Safjan, L. Bosek. Warszawa 2016, Nb. 5 do art. 183. 
prawnych uczestników procesu karnego. Powyższy wniosek wynika m.in. z przewidzianych $\mathrm{w}$ art. $523 \S 2$ i 3 k.p.k. przedmiotowych ograniczeń kasacji dla stron, zgodnie z którymi kasację na korzyść można wnieść jedynie w razie skazania oskarżonego na karę pozbawienia wolności bez warunkowego zawieszenia jej wykonania, a kasację na niekorzyść jedynie $\mathrm{w}$ razie jego uniewinnienia lub umorzenia postępowania. Można go wywieść również z art. $523 \S 1$ k.p.k., zgodnie z którym podstawę kasacji mogą stanowić wyłącznie uchybienia przybierające postać rażącego (tj. kwalifikowanego) naruszenia prawa, w dodatku jedynie te $\mathrm{z}$ nich, które mogły mieć istotny (tj. kwalifikowany) wpływ na treść zaskarżonego orzeczenia. Myśl ta wypływa zresztą już z samej analizy powagi powierzonych temu sądowi spraw, skatalogowanych w art. 1 Ustawy z dnia 8 grudnia 2017 r. o Sądzie Najwyższym²3 .

Jedynie na marginesie warto zauważyć, że w chwili pisania tych słów Izba Karna Sądu Najwyższego liczyła zaledwie dwudziestu pięciu sędziów $^{24}$, mimo że jej zadania obejmują swym zasięgiem terytorium całego kraju. Pominięto $\mathrm{w}$ tym miejscu fakt, że zgodnie z art. $35 \$ 3 \mathrm{zd}$. 1 u.s.n. do udziału w rozpoznaniu sprawy należącej do kompetencji Izby Karnej mogą być wyznaczeni również sędziowie z innych izb. Tym bardziej że częściej to właśnie sędziowie Izby Karnej wyznaczani są do rozpoznawania spraw co do zasady nieprzypisanych im w drodze ustawy, co w ostatnim czasie miało miejsce m.in. w związku z wątpliwościami dotyczącymi statusu Izby Dyscyplinarnej Sądu Najwyższego (nie wspominając o przekazaniu jej wszystkich zadań zniesionej 3 kwietnia 2018 r. Izby Wojskowej; zob. art. 133 § 1 i 3 w zw. z art. 24 u.s.n.).

Mówiąc prościej, najważniejszy sąd w kraju nie powinien zajmować się sprawami bagatelnymi, a taką jest bez wątpienia sprawa dotycząca kasacji na niekorzyść, która z uwagi na upływ określonego terminu i treść zaskarżonego orzeczenia nie może być rozpoznana zgodnie z żądaniem skarżącego i w której to sprawie nie można już polepszyć sytuacji oskarżonego. Wydaje się, że nie jest nadzorem judykacyjnym w rozumieniu art. 183 ust. 1 Konstytucji RP sytuacja, w której - jak miało to miejsce we wszystkich przywołanych wcześniej orzeczeniach oddalających kasację trzech z dwudziestu pięciu sędziów Sądu Najwyższego zmuszonych jest pochylać się nad orzeczeniem, o którym od razu wiedzą, że bez względu

${ }^{23}$ Dz.U. 2019, poz. 825 oraz Dz.U. 2020, poz. 190 [dalej jako: u.s.n.].

${ }^{24} \mathrm{http} / / /$ www.sn.pl/osadzienajwyzszym/SitePages/Organizacja.aspx?ListName=Org_IK [dostęp: 22.03.2020]. Sam Sąd Najwyższy postulował utworzenie w Izbie Karnej 32 etatów sędziowskich (Informacja o działalności Sądu Najwyższego w roku 2018 oraz Informacja o działalności Izby Dyscyplinarnej Sądu Najwyższego w roku 2018. Warszawa 2019, s. 136). 
na ewentualnie dostrzeżone uchybienia nie będą mieli możliwości jego zmiany albo uchylenia.

Przyjęcie interpretacji, w myśl której kasacja na niekorzyść wniesiona po upływie roku od daty uprawomocnienia się orzeczenia, które nie mogłoby być dla oskarżonego już bardziej korzystne, nie wymaga „rozpoznania sprawy" w rozumieniu art. 537 § 1 in principio k.p.k., a w konsekwencji jej oddalenia, prowadziłoby do następujących wniosków. Po pierwsze, jeżeli okoliczność ta zostałaby dostrzeżona na etapie postępowania przed Sądem Najwyższym, to mógłby on pozostawić przyjętą kasację bez rozpoznania, co - zgodnie z art. $531 \S 1$ zd. 2 w zw. z art. $534 \S 1$ in principio k.p.k. - oznacza, że czynność ta wymagałaby zaangażowania wyłącznie jednego sędziego. Po drugie, jeżeli ta sama okoliczność zostałaby dostrzeżona już na etapie badania kasacji przez prezesa sądu, do którego ją wniesiono, to miałby on kompetencję do odmowy jej przyjęcia w trybie art. 530 § 2 k.p.k., co z kolei w ogóle wykluczałoby konieczność angażowania sędziów Sądu Najwyższego, którzy w tym samym czasie mogliby skupić się na rozpoznawaniu spraw rzeczywiście wymagających interwencji sądu aż tak wysokiego szczebla. Jak bowiem trafnie wskazuje się w doktrynie prawa karnego procesowego, to właśnie od sprawności tzw. postępowania przedkasacyjnego, polegającego na wstępnym filtrowaniu skarg kasacyjnych przez prezesa sądu odwoławczego, zależy wyselekcjonowanie skarg rzeczywiście zasługujących na rozpoznanie i uchronienie sądu kasacyjnego przed zalaniem go nadmierną liczbą spraw ${ }^{25}$.

W świetle ostatniej z postawionych wyżej tez do rozstrzygnięcia pozostaje jedynie kwestia ewentualnej podstawy prawnej do „odsiewania” opisywanego typu kasacji już na etapie postępowania przedkasacyjnego. Należy przyjąć, że skoro kasacja spełniająca oba wskazane wcześniej warunki (dotyczące czasu jej wniesienia i treści zaskarżonego orzeczenia) bez względu na merytoryczną wartość postawionych w niej zarzutów i tak nie będzie mogła wywołać żadnych skutków prawnych, to w pewnym sensie nie różni się znacznie np. od środka odwoławczego wniesionego od orzeczenia sądu odwoławczego wydanego na skutek rozpoznania apelacji. W związku z tym również i ją należałoby potraktować jako „niedopuszczalną z mocy ustawy” w rozumieniu art. 429 § 1 in fine k.p.k. ${ }^{26}$, która to przesłanka - z mocy odesłania zawartego w art. 530 $\S 2$ k.p.k. - upoważnia właśnie do odmowy przyjęcia wniesionego środka zaskarżenia.

${ }^{25}$ S. Waltoś: Nowa kasacja w procesie karnym. Pal. 1996, nr 1-2, s. 23; S. Waltoś, P. Hofmański: Proces karny. Zarys systemu. Wyd. 11. Warszawa 2013, s. 549-550.

${ }^{26}$ Zob. post. SN z dnia 22 marca 2000 r., V KZ 23/00. OSNKW 2000, nr 5-6, poz. 52. 
Analizując zagadnienie prawidłowości czynności procesowych w procesie karnym, wskazuje się, że do warunków niewadliwości takich czynności należy również spełnienie wymogów dotyczących ter$m^{m i n u}{ }^{27}$. Innymi słowy, źródłem niedopuszczalności czynności prawnej może być także jej zbyt późne dokonanie, mimo że w innym wypadku ta sama akcja procesowa zostałaby uznana za w pełni prawidłową. $\mathrm{W}$ literaturze nie ma zgodności co do tego, czy ustawodawca, chcąc uznać daną czynność za niedopuszczalną, powinien posłużyć się tym pojęciem wprost (ujęcie wąskie) czy też wystarczające jest użycie wyrażenia równoznacznego, jak chociażby „nie wolno” czy „nie prowadzi się” (ujęcie szerokie $)^{28}$. Problem ten nie dotyczy jednak komentowanego zagadnienia, jako że w art. 524 § 3 k.p.k. odwołano się wprost do konstrukcji niedopuszczalności, o której mowa $\mathrm{w}$ art. $429 \$ 1$ in fine $\mathrm{w}$ zw. $\mathrm{z}$ art. 530 $\S 2$ k.p.k. Co prawda analizujący tę problematykę K. Woźniewski przychyla się do stanowiska, w myśl którego upływ wskazanego terminu nie zabrania wniesienia kasacji na niekorzyść, jednak wydaje się, że w pewnym stopniu może to wynikać z niedostrzegania sytuacji, w których zaskarżone orzeczenie nie może być już dla oskarżonego w jakikolwiek sposób korzystniejsze. Świadczy o tym fragment, zgodnie z którym argumentem przemawiającym za rozpoznaniem takiej kasacji na zasadach ogólnych jest właśnie ewentualna możliwość wydania decyzji procesowej na korzyść oskarżonego ${ }^{29}$. Równocześnie Autor ten przyjmuje, że w odniesieniu do kasacji ustawa zawiera jeszcze jedną normę określającą niedopuszczalność akcji procesowej. Chodzi tu o opisaną w art. 539 k.p.k. niedopuszczalność wniesienia kasacji od orzeczenia Sądu Najwyższego zapadłego właśnie w następstwie rozpoznania kasacji (tzw. superkasacja), co także prowadzi do konieczności odmowy przyjęcia takiej skargi. W razie upływu terminu i braku choćby hipotetycznej zmiany zaskarżonego orzeczenia na korzyść oskarżonego oba zakazy mają w istocie ten sam charakter prawny (wszak oba prowadzą do bezwzględnej niemożliwości zmodyfikowania zaskarżonego orzeczenia), w związku z czym również ich przekroczenie (złamanie) należałoby traktować jednakowo (być może właśnie z tego wynika posłużenie się przez przywołanego Autora wyrażeniem ,jeszcze jedną normę").

27 K. Woźniewski: Prawidłowość czynności procesowych $w$ polskim procesie karnym. Gdańsk 2010, s. 139.

${ }^{28}$ Ibidem, s. 170; interesujący przegląd stanowisk w tym względzie prezentuje B. JANUSZ-PoHL: O konstrukcji niedopuszczalności czynności karnoprocesowych. RPEiS 2014, z. 4, s. 161 i nast.; EADEM: Przyczynek do rozważań o formalnym i konwencjonalnym charakterze procesu karnego. IN 2014, nr 4, s. 106 i nast.

${ }^{29}$ K. WoźNIEwski: Prawidłowość czynności procesowych..., s. 168. 
Umożliwienie wydawania tego typu decyzji procesowych prezesom sądów okręgowych i apelacyjnych nie rodziłoby obaw o zacieranie subtelnej granicy pomiędzy sprawdzaniem warunków formalnych kasacji a ich wstępnym badaniem merytorycznym, sformułowanych na gruncie problemu badania w postępowaniu przedkasacyjnym, czy powoływane przez stronę uchybienia stanowią dopuszczalne podstawy kasacji ${ }^{30}$. Przepis art. $524 \S 3$ k.p.k. nie posługuje się tak ocennymi kryteriami jak „rażące naruszenie prawa” czy „istotny wpływ na treść orzeczenia”. Prezesi sądów II instancji nie ocenialiby rangi uchybień czy ich znaczenia w procesie, a przez to odpadłaby obawa o wykonywanie przez nich tego, co z mocy ustawy powinno należeć wyłącznie do zadań sądu kasacyjnego. Równocześnie warto zwrócić uwagę, że zgodnie z art. 530 § 3 zd. 1 k.p.k. zarządzenia o odmowie przyjęcia kasacji same w sobie podlegają zaskarżeniu do Sądu Najwyższego. Zatem przy zaakceptowaniu tego ujęcia strony nie zostałyby pozbawione prawa do zainicjowania $\mathrm{w}$ tym zakresie kontroli sprawowanej przez najwyższą instancję sądową (prawidłowość tego zarządzenia częściowo byłaby zresztą badana również na etapie podejmowania decyzji o pozostawieniu skargi bez rozpoznania, kiedy to bada się również, czy przyjęcie kasacji nie nastąpiło pomimo uchybienia przepisom wymienionym $\mathrm{w}$ art. 530 § 2 k.p.k.), co czyni bezzasadnym możliwy do postawienia proponowanej tu metodzie wykładniczej zarzut przedkładania względów ekonomiki procesowej nad rzetelnością postępowania. Jedynie na marginesie głównych rozważań warto odnotować, że w myśl art. $530 \S 3$ zd. 2 k.p.k. sąd kasacyjny rozpoznaje takie zażalenia jednoosobowo, przez co przyjęcie forsowanego poglądu wpłynęłoby na jego znaczące odciążenie względem stanu zastanego nawet przy skrajnie nierealistycznym założeniu, że strony skarżyłyby wszystkie zarządzenia wydane w tym przedmiocie przez prezesów sądów.

\subsection{Wykładnia funkcjonalna}

Próbując sprawdzić, czy i ewentualnie jaki wpływ na wynik wykładni systemowej będzie miała analiza wskazanego w tytule pracy przepisu przez pryzmat dyrektyw wykładni funkcjonalnej, należy mieć na uwadze przede wszystkim to, że jego celem niewątpliwie było - w myśl formuły favor defensionis - danie oskarżonemu dodatkowej szansy na zmodyfikowanie bądź uchylenie prawomocnego wyroku na jego korzyść, pomimo że środek zaskarżenia wpłynął wyłącznie na jego niekorzyść

30 S. Waltoś: Nowa kasacja w procesie karnym..., s. 23; S. Waltoś, P. Hofmański: Proces karny..., s. 550. 
(por. art. 434 § 2 k.p.k.). Przyjęcie wykładni, zgodnie z którą kasacja wniesiona po upływie roku od dnia uprawomocnienia się zaskarżonego wyroku, którego treść nie mogłaby być dla oskarżonego już bardziej korzystna, powinna podlegać oddaleniu po jej merytorycznym rozpoznaniu, tego celu bynajmniej nie realizuje. Prowadzi ona do sytuacji, w której prezes sądu odwoławczego zmuszony jest przyjmować kasację, o której wie, że Sąd Najwyższy rozpozna ją właściwie dla samego rozpoznania, skoro ex ante znany jest wynik postępowania, które teoretycznie dopiero ma zostać rzetelnie przeprowadzone.

$\mathrm{Na}$ drodze do przyjęcia wykładni przeciwnej nie stoi z kolei ani cel samego art. 524 § 3 k.p.k., ani też cel art. 530 § 2 i art. 531 § 1 k.p.k., mających wszak służyć właśnie temu, ażeby sąd kasacyjny nie był zmuszony do rozpoznawania spraw, które z przyczyn o charakterze proceduralnym nie zasługują na uczynienie ich przedmiotem rozstrzygnięcia trzech sędziów najważniejszego sądu w kraju. Warto zauważyć, że literalna wykładnia art. 29 § 2 k.p.k. w brzmieniu nadanym temu przepisowi Ustawą z dnia 19 lipca 2019 r. o zmianie ustawy - Kodeks postępowania karnego oraz niektórych innych ustaw ${ }^{31}$ nakazuje Sądowi Najwyższemu rozpoznawać wszystkie kasacje zawierające wniosek o wymierzenie oskarżonemu kary dożywotniego pozbawienia wolności (który z uwagi na treść art. 537 k.p.k., rzecz jasna, nigdy nie mógłby zostać uwzględniony) w aż pięcioosobowym składzie, niemniej z uwagi na ograniczenia redakcyjne oraz przyjęty zakres tematyczny pracy zagadnienie prawidłowej wykładni art. $29 \$ 2$ k.p.k. nie będzie przedmiotem dalszych rozważań. Jeszcze szerszy, bo aż siedmioosobowy skład przewidziano z kolei w art. 534 $\S 2$ in principio k.p.k. dla kasacji dotyczących orzeczeń samego Sądu Najwyższego, co może mieć miejsce w np.:

1) niektórych sprawach podlegających orzecznictwu sądów wojskowych, w których - zgodnie z art. $655 \$ 1$ pkt 1 i 2 k.p.k. - sąd ten rozpoznaje z jednej strony (a) środki odwoławcze od orzeczeń i zarządzeń wydanych w I instancji przez wojskowe sądy okręgowe, a z drugiej strony (b) kasacje na orzeczenia wydane $\mathrm{w}$ następstwie rozpoznania takich środków odwoławczych;

2) sprawach przejętych przez Sąd Najwyższy do własnego rozpoznania w trybie art. $441 \S 5$ k.p.k. ${ }^{32}$.

3) przypadku wydania przez Sąd Najwyższy wyroku uniewinniającego, o którym mowa w art. $547 \S 3$ zd. 1 k.p.k.

Podsumowując powyższe uwagi, można się wręcz pokusić o tezę, że postępowanie, w którym większa liczba sędziów sądu stojącego na sa-

31 Dz.U. poz. 1694.

32 B. ŁUKOWIAK: Zakres podmiotowy zwiazania..., s. 64-65. 
mym szczycie struktury sądownictwa w Polsce pochyla się nad orzeczeniem, o którym wiedzą, że i tak nie ulegnie ono wzruszeniu, w istocie jest jedynie karykaturą rzetelnego postępowania. Krytykowany w tej pracy wąski sposób interpretacji art. $524 \S 3$ k.p.k. prowadzi przy tym do zmarnotrawienia publicznych środków oraz czasu, przejawiającego się w niepotrzebnym przesyłaniu akt (liczących nieraz ponad 300 tomów ${ }^{33}$ ) z sądu odwoławczego do sądu kasacyjnego oraz w angażowaniu sędziów i ich asystentów, jak również obrońców czy pełnomocników, co bez wątpienia nie było celem jego wprowadzenia.

\section{Podsumowanie}

Przedstawione wyżej argumenty natury systemowej i funkcjonalnej dowodzą, że komentowany przepis należy rozumieć jako nakazujący Sądowi Najwyższemu - w przypadku wniesienia kasacji spełniającej łącznie oba wskazane wcześniej warunki (dotyczące czasu jej wniesienia i treści zaskarżonego orzeczenia) - pozostawienie przyjętego środka zaskarżenia bez rozpoznania $\mathrm{w}$ trybie art. $531 \S 2$ k.p.k., zatem w drodze postanowienia wydawanego w składzie jednego sędziego na posiedzeniu bez udziału stron, a nawet szerzej - jako zobowiązujący do odmowy przyjęcia takiej kasacji już na etapie postępowania przedkasacyjnego, o którym mowa w art. $530 \S 2$ k.p.k. W obu przypadkach podstawę wydania takiej decyzji powinna stanowić okoliczność, że wniesiony środek jest niedopuszczalny z mocy ustawy (art. $429 \S 1$ in fine $\mathrm{w}$ zw. $\mathrm{z}$ art. 524 $\S 3$ k.p.k.).

Na zakończenie wypada wyrazić nadzieję, że postulowana zmiana sposobu interpretacji omawianych unormowań przynajmniej w jakimś zakresie przyczyni się do poprawy aktualnego stanu obciążenia Sądu Najwyższego i odwrócenia tendencji spadkowej w zakresie efektywności działania tego organu w sprawach karnych, których doskonałą ilustracją są dane zawarte $\mathrm{w}$ Tabeli 1 . Wynika z nich, że rokrocznie wzrasta liczba spraw kasacyjnych pozostałych do załatwienia w następnym okresie. Tym bardziej że dotychczasowe niedomagania z pewnością zostaną w najbliż-

33 Informacja..., s. 181 (w 2018 r. akta sprawy odpowiedzialności karnej za mającą miejsce w 2006 r. katastrofę budowlaną polegającą na zawaleniu się dachu jednej z hal liczyły rekordowe 320 tomów; zob. wyr. SN z dnia 29 listopada 2018 r., IV KK 247/18. LEX nr 2586038). Z doniesień medialnych wynika, że akta jednej z najgłośniejszych w ostatnich latach spraw (z uwzględnieniem akt zebranych $\mathrm{w}$ toku postępowania przygotowawczego) liczyły tysiące tomów (!), a do ich przewożenia konieczne było użycie ciężarówek źródło:https://tvn24.pl/polska/tysiace-tomow-akt-w-sprawie-amber-gold-juz-w-gdanskim-sadzie-jest-tez-akt-oskarzenia-ra554591 [dostęp: 25.03.2020]. 
szym czasie spotęgowane za sprawą problemów narosłych w związku ze skutkami pandemii wirusa SARS-CoV-2.

Tabela 1. Statystyka spraw kasacyjnych w Izbie Karnej Sądu Najwyższego w latach 2015-2019

\begin{tabular}{|l|c|c|c|}
\hline \multicolumn{1}{|c|}{ Rok } & Wpłynęło & Załatwiono & Pozostało \\
\hline 2015 & 1778 & 1876 & 509 \\
\hline 2016 & 1821 & 1816 & 515 \\
\hline 2017 & 2163 & 1905 & 773 \\
\hline 2018 & 2717 & 1855 & 1635 \\
\hline 2019 & 2647 & 2633 & 1649 \\
\hline
\end{tabular}

Opracowanie własne na podstawie: Izba Karna Sądu Najwyższego Statystyka Ruchu Spraw.

Źródło: http://www.sn.pl/sprawy/SitePages/Statystyki_ruchu_spraw.aspx?ListName= Statystyka_Izba_Karna [dostęp: 27.05.2020].

\section{Bibliografia}

\section{Literatura}

Grzegorczyk T. W: T. Grzegorczyk, J. Tylman: Polskie postępowanie karne. Wyd. 7. Warszawa 2009.

Janusz-PoHL B.: O konstrukcji niedopuszczalności czynności karnoprocesowych. RPEiS 2014, z. 4.

Janusz-PoHL B.: Przyczynek do rozważań o formalnym i konwencjonalnym charakterze procesu karnego. IN 2014, nr 4.

Kozielewicz W. W: Kodeks postępowania karnego. T. I. Komentarz. Art. 1-424. Red. D. Drajewicz. Warszawa 2020.

ŁUKOWIAK B.: Zakres podmiotowy zwiazania zapatrywaniami prawnymi sadu odwoławczego w postępowaniu karnym. „Veritas Iuris” 2019, nr 1.

Matras J. W: Kodeks postępowania karnego. Komentarz. Red. K. DudKa. Warszawa 2018.

NowIKOwsKI I.: Funkcja gwarancyjna terminów $w$ polskim kodeksie postępowania karnego. „Studia Iuridica Lublinensia” 2013, nr 20.

Nowiкоwsкi I.: O regułach obliczania terminów $w$ procesie karnym (kwestie wybrane). W: Teoretyczne $i$ praktyczne problemy wspótczesnego prawa karnego. Ksiegga jubileuszowa dedykowana Profesorowi Tadeuszowi Bojarskiemu. Red. A. Michalska-Warias, I. Nowikowski, J. Piórkowska-Flieger. Lublin 2011.

Sakowicz A. W: Kodeks postępowania karnego. Komentarz. Wyd. 9. Red. Idem. Warszawa 2020.

Świecki D. W: Kodeks postępowania karnego. Komentarz. Wyd. 4. Red. J. SKorupKA. Warszawa 2020.

Waltoś S.: Nowa kasacja w procesie karnym. Pal. 1996, nr 1-2.

Waltoś S., Hofmański P.: Proces karny. Zarys systemu. Wyd. 11. Warszawa 2013. 
Wiliński P., Karlik P. W: Konstytucja RP. T. II. Komentarz. Art. 87-243. Red. M. SAFJan, L. BoseK. Warszawa 2016.

WoźNIEWsKi K.: Prawidłowość czynności procesowych $w$ polskim procesie karnym. Gdańsk 2010.

ZabŁocKi S. W: Kodeks postępowania karnego. Komentarz. T. I. Red. Z. GosTYŃsKI. Warszawa 1998.

ZIELIŃSKI M.: Koncepcja derywacyjna wykładni a wykładnia w orzecznictwie Izby Karnej i Izby Wojskowej Sadu Najwyższego. W: Zagadnienia prawa dowodowego. Red. J. Godyń, M. HudziK, L.K. PAPrZYCKI. Warszawa 2011.

\section{Akty prawne}

Ustawa z dnia 2 kwietnia 1997 r. - Konstytucja Rzeczypospolitej Polskiej, Dz.U. nr 78, poz. 483, Dz.U. 2001, nr 28, poz. 319, Dz.U. 2006, nr 200, poz. 1471 oraz Dz.U. 2009, nr 114, poz. 946.

Ustawa z dnia 19 kwietnia 1969 r. - Kodeks postępowania karnego, Dz.U. nr 13, poz. 96 ze zm.

Ustawa z dnia 21 grudnia 1990 r. o zawodzie lekarza weterynarii i izbach lekarsko-weterynaryjnych, Dz.U. 2019, poz. 1140.

Ustawa z dnia 19 kwietnia 1991 r. o izbach aptekarskich, Dz.U. 2019, poz. 1419.

Ustawa z dnia 6 czerwca 1997 r. - Kodeks postępowania karnego, Dz.U. 2020, poz. 30, 413 i 568 .

Ustawa z dnia 10 września 1999 r. - Kodeks karny skarbowy, Dz.U. 2020, poz. 19,568 i 695 .

Ustawa z dnia 27 lipca 2001 r. o diagnostyce laboratoryjnej, Dz.U. 2019, poz. 849 oraz Dz.U. 2020, poz. 567.

Ustawa z dnia 24 sierpnia 2001 r. - Kodeks postępowania w sprawach o wykroczenia, Dz.U. 2020, poz. 729.

Ustawa z dnia 28 października 2002 r. o odpowiedzialności podmiotów zbiorowych za czyny zabronione pod groźbą kary, Dz.U. 2020, poz. 358.

Ustawa z dnia 18 października 2006 r. o ujawnianiu informacji o dokumentach organów bezpieczeństwa państwa z lat 1944-1990 oraz treści tych dokumentów, Dz.U. 2020, poz. 306 i 322.

Ustawa z dnia 2 grudnia 2009 r. o izbach lekarskich, Dz.U. 2019, poz. 965.

Ustawa z dnia 1 lipca 2011 r. o samorządzie pielęgniarek i położnych, Dz.U. 2018, poz. 916.

Ustawa z dnia 25 września 2015 r. o zawodzie fizjoterapeuty, Dz.U. 2019, poz. 952 oraz Dz.U. 2020, poz. 567.

Ustawa z dnia 11 marca 2016 r. o zmianie ustawy - Kodeks postępowania karnego oraz niektórych innych ustaw, Dz.U. poz. 437 i 2103 oraz Dz.U. 2017, poz. 1139 i 1452.

Ustawa z dnia 8 grudnia 2017 r. o Sądzie Najwyższym, Dz.U. 2019, poz. 825 oraz Dz.U. 2020, poz. 190.

Ustawa z dnia 19 lipca 2019 r. o zmianie ustawy - Kodeks postępowania karnego oraz niektórych innych ustaw, Dz.U. poz. 1694. 
Ustawa z dnia 2 marca 2020 r. o szczególnych rozwiązaniach związanych z zapobieganiem, przeciwdziałaniem i zwalczaniem COVID-19, innych chorób zakaźnych oraz wywołanych nimi sytuacji kryzysowych, Dz.U. poz. 374, 567, 568 i 695.

Rozporządzenie Prezydenta Rzeczypospolitej Polskiej z dnia 19 marca 1928 r. Kodeks postępowania karnego, Dz.U. 1949, nr 33, poz. 243.

\section{Orzecznictwo}

Uchw. Składu Siedmiu Sędziów SN z dnia 29 października 2012 r., I KZP 15/12. OSNKW 2012, nr 11, poz. 111, s. 1.

Wyr. SN z dnia 28 lutego 2006 r., V KK 472/05. OSNKW 2006, nr 5, poz. 48. Wyr. SN z dnia 31 stycznia 2017 r., V KK 360/16. OSNKW 2017, nr 6, poz. 34. Wyr. SN z dnia 29 listopada 2018 r., IV KK 247/18. LEX nr 2586038.

Post. SN z dnia 22 marca 2000 r., V KZ 23/00. OSNKW 2000, nr 5-6, poz. 52.

Post. SN z dnia 31 marca 2005 r., III KK 182/04. OSNSK 2005, poz. 645.

Post. SN z dnia 10 września 2009 r., V KK 55/09. OSNSK 2009, nr 1, poz. 1860. Post. SN z dnia 18 stycznia 2012 r., V KK 329/11. OSNKW 2012, nr 3, poz. 32. Post. SN z dnia 17 grudnia 2013 r., SDI 49/13. LEX nr 1403914. Post. SN z dnia 31 stycznia 2017 r., V KK 333/16. LEX nr 2255440.

\section{Źródła internetowe}

https://tvn24.pl/polska/tysiace-tomow-akt-w-sprawie-amber-gold-juz-w-gdans kim-sadzie-jest-tez-akt-oskarzenia-ra554591 [dostęp: 25.03.2020].

http://www.sn.pl/sprawy/SitePages/Statystyki_ruchu_spraw.aspx?ListName= Statystyka_Izba_Karna [dostęp: 27.05.2020]. 